\title{
Proximal aortic surgery in the elderly: Is age just a number?
}

\author{
Walker M. Blanding, BS, ${ }^{\mathrm{a}}$ and Leora B. Balsam, $\mathrm{MD}^{\mathrm{b}}$
}

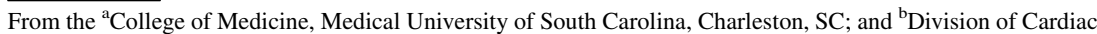
Surgery, UMass Memorial Medical Center, Worcester, Mass.

Disclosures: Authors have nothing to disclose with regard to commercial support.

Received for publication May 15, 2018; revisions received May 15, 2018; accepted for publication May 16, 2018; available ahead of print June 27, 2018.

Address for reprints: Leora B. Balsam, MD, Division of Cardiac Surgery, UMass Memorial Medical Center, University Campus, 55 Lake Ave N, Worcester, MA 01655 (E-mail: leora.balsam@umassmemorial.org).

J Thorac Cardiovasc Surg 2019;157:64-5

$0022-5223 / \$ 36.00$

Copyright (c) 2018 by The American Association for Thoracic Surgery

https://doi.org/10.1016/j.jtcvs.2018.05.054
}

What's in a number? Age may be that, and as surgeons we are familiar with the notion that older patients have less reserve. As such, older patients face challenges that are different than those faced by younger ones after cardiac surgery. In recent years, there has been increasing focus on quantifying this surgical reserve, and surgical risk calculators and frailty indices may be helpful tools. Worse functional status and a higher burden of comorbidities go hand in hand with older age, and all these factors may influence the postsurgical outcome.

In this issue of the Journal, Wanamaker and colleagues ${ }^{1}$ present a single-center experience with proximal aortic surgery in an elderly population. Between the years of 2002 and 2013, a total of 415 patients older than 70 years underwent surgery for a variety of aortic pathologies, including aneurysmal disease, porcelain aorta, and type A dissection. In their study, Wanamaker and colleagues ${ }^{1}$ compared the outcomes of 2 different age groups: septuagenarians and those older than 80 years. Overall, the burden of comorbidities was higher in the octogenarians, and their operative mortality was also higher. In their statistical analysis, Wanamaker and colleagues ${ }^{1}$ found that age alone was not an independent predictor of operative mortality; rather, the etiology of aortic disease and severity of comorbidities were independent predictors. Not unexpectedly, they also found an association between advanced age and impaired long-term survival. Wanamaker and colleagues ${ }^{1}$ concluded that proximal aortic surgery can be performed safely and with reasonable outcomes in both septuagenarians and octogenarians, and that advanced age alone should not be an absolute contraindication for surgery.

Wanamaker and colleagues' work $^{1}$ holds particular importance in an era of an actively aging North American population. The downstream effect is that surgeons are likely to encounter more of these elderly patients under both elective and urgent circumstances, and knowing when to operate and on whom is important. Recent reports suggest that acceptable results and comparable operative

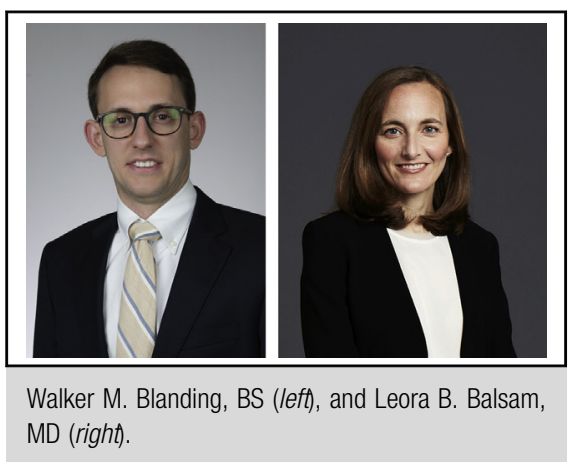

Central Message

A new study shows that advanced age acts as a marker of higher comorbidity burden in proximal aortic surgery, rather than an indicator for operative mortality.

See Article page 53.

mortality can be achieved in elderly patients undergoing complex cardiac operations, ${ }^{2-5}$ which is a testament to advances at multiple levels, including anesthetic, surgical, and postsurgical care. But careful patient selection is likely the key to success, and this particular study does not guide the reader regarding how best to identify patients who will benefit from surgery. This decision making, or clinical judgment, is where the science of medicine meets its art.

The findings in this study align with previous reports showing higher operative mortality and late mortality in the elderly population ${ }^{6,7}$; after controlling for comorbidities and operative indication, however, 30-day mortality and readmission rates in this study were not statistically different between septuagenarians and octogenarians. This suggests that advanced age confers operative risk only to the extent that it correlates with a higher comorbidity burden and higher risk aortic pathology.

The study caries 2 significant limitations beyond those intrinsic to its design, both of which are acknowledged. One of these is the lack of younger patients as a control group; given the paucity of younger patients without connective tissue disorders or previous operation presenting with indications for proximal aortic surgery, however, this type of data may be neither feasible to gather nor clinically significant. The second is lack of data on similar pathologies in age-matched control subjects who 
were turned away from the operating room either at initial presentation or after surgical consultation. This limits the reader's ability to determine whether surgery is the correct option even for a patient with advanced age and low comorbidity burden.

Nevertheless, the study does demonstrate that although advanced age may go hand in hand with higher comorbidity burden and a greater likelihood for postsurgical discharge to a rehabilitation facility, for carefully selected patients, age may not predict operative risk in proximal aortic surgery.

\section{References}

1. Wanamaker KM, Hirji SA, Ramirez Del Val F, Yammine M, Lee J, McGurk S, et al. Proximal aortic surgery in the elderly population: is advanced age a contraindication for surgery? J Thorac Cardiovasc Surg. 2019;157:53-63.
2. Ghanta RK, Shekar OS, McGurk S, Rosborough DM, Aranki SF. Long-term survival and quality of life justify cardiac surgery in the very elderly patient. Ann Thorac Surg. 2011;92:851-7.

3. Thourani VH, Myung R, Kilgo P, Thompson K, Puskas JD, Lattouf OM, et al. Long-term outcomes after isolated aortic valve replacement in octogenarians: a modern perspective. Ann Thorac Surg. 2008;86:1458-64; discussion 1464-5.

4. Piccardo A, Regesta T, Zannis K, Gariboldi V, Pansini S, Tapia M, et al. Outcomes after surgical treatment for type A acute aortic dissection in octogenarians: a multicenter study. Ann Thorac Surg. 2009;88:491-7.

5. Mehta RH, O'Gara PT, Bossone E, Nienaber CA, Myrmel T, Cooper JV, et al Acute type A aortic dissection in the elderly: clinical characteristics, management, and outcomes in the current era. J Am Coll Cardiol. 2002;40:685-92.

6. Okita Y, Ando M, Minatoya K, Tagusari O, Kitamura S, Nakajjma N, et al Early and long-term results of surgery for aneurysms of the thoracic aorta in septuagenarians and octogenarians. Eur J Cardiothorac Surg. 1999;16: 317-23.

7. Kunihara T, Aicher D, Asano M, Takahashi H, Heimann D, Sata F, et al Risk factors for prophylactic proximal aortic replacement in the current era Clin Res Cardiol. 2014;103:431-40. 